\title{
Edukacja dialogowa a kontekst kulturowy szkoły w tle koncepcji Jerome'a S. Brunera. Spotkania ze światem kulturowo różnym w klasie szkolnej
}

Streszczenie: Artykuł ma charakter teoretyczny i jest refleksją nad kulturowym kontekstem szkoły z uwzględnieniem koncepcji Jerome’a S. Brunera. Dotychczasowe badania nad polską szkołą i wielokulturowością jej uczniów wskazują na różne jej modele i potrzebę realizacji edukacji dialogowej. Skłania to do określenia, w jaki sposób przebiega uczenie się w wielokulturowej szkole z obowiązującym $\mathrm{w}$ niej dyskursem. Analiza teoretyczna podjętych w artykule problemów dotyczy roli współczesnej szkoły i jej spotkań ze światem kulturowo różnym, miejsca międzykulturowego dialogu i dialogowego uczenia się. W odwołaniu do koncepcji Jerome’a S. Brunera, w artykule podjęto próbę określenia znaczenia różnych habitusów uczestników szkolnej edukacji i ich wpływu na rozwój i kulturę samej szkoły. Podjętym zagadnieniem teoretycznym jest także reprodukcja kultury „większości” w procesie edukacji szkolnej i konstruowanie przez uczniów wiedzy o świecie, nadawaniu mu znaczeń w warunkach kulturowej różnorodności. Idea edukacji dialogowej z koncepcją J.S. Brunera i jej teoretyczne konteksty zostały zestawione z przykładami praktyki edukacyjnej i realiami szkolnej rzeczywistości.

Słowa kluczowe: edukacja dialogowa, kultura, koncepcja Jerome’a S. Brunera, wielokulturowość, edukacja międzykulturowa

\section{Wprowadzenie}

W naukach społecznych, w tym w pedagogice, jedną z głównych współcześnie orientacji jest uznanie kultury za znaczącą kategorię w szeroko pojętej edukacji. Dał temu wyraz J.S. Bruner (2010), uznając ją za czynnik rozwoju jednostki i grup, a kulturę szkoły określił jako uczącą się wspólnotę. „Kultura - jak pisał - sama w sobie jest wytworem człowieka, kształtuje zarówno ludzki umysł, jak i umożliwia jego funkcjonowanie. Zgodnie z tym poglądem uczenie się i myślenie zawsze sytuują się w środowisku kulturowym i zależne są od stopnia wykorzystania jego zasobów" (Bruner, 2010, s. 17). Rodzi to 
pytania o przebieg uczenia się $\mathrm{w}$ wielokulturowej szkole $\mathrm{z}$ obowiązującym w niej dyskursem, wyznaczanym przez „większość”. Użycie określeń typu „większość” i „mniejszość” implikuje pojęcie stratyfikacji i nierówności społecznych. Stawia przed współczesną szkołą nowe wyzwania we wzajemnych spotkaniach ze światem kulturowo różnym, czyniąc z niej miejsce międzykulturowego dialogu i dialogowego uczenia się. Wielość habitusów uczestników szkolnej edukacji może stanowić predyktor ich rozwoju i płaszczyznę dla rozwoju kultury samej szkoły, o ile nie zdominuje jej reprodukcja kultury „większości”. W edukacji szkolnej lepsze wyposażenie uczniów w wiedzę powinno opierać się o dialog i prowadzić do rozwoju indywidualnego każdego z uczestników przestrzeni szkolnej, niezależnie od ich proweniencji narodowej i etnicznej. Reprezentowana przez nich wielość kultur w dokonującym się procesie dydaktycznym generuje wzajemne konstruowanie wiedzy o świecie i nadawanie mu określonych znaczeń. Czy istotnie tak się to odbywa w praktyce szkolnej? Jaką rolę spełnia w tych procesach nauczyciel zobligowany do realizacji programu szkolnego i narzucania obowiązującego w dydaktyce dyskursu? Co zyskują, a co tracą obie strony - „większość” i „mniejszość” $\mathrm{w}$ procesie dydaktycznym?

\section{Psychokulturowa koncepcja szkoły Jerome’a S. Brunera - „wzajemność wspólnoty uczących się"}

Wielość pojawiających się pytań odzwierciedla złożoność sytuacji szkolnych, zwłaszcza w kontekście wielokulturowej klasy, a jednocześnie skłania do namysłu nad znaczeniem kultury w procesie edukacji. Liczne teorie bowiem, w tym przedmiotowa teoria kultury edukacji J. Brunera, nie znajdują swego potwierdzenia w rzeczywistości i praktyce szkoły. I jak pisał sam Bruner, „z całą pewnością praktyka szkolna stanowi zaledwie niewielką część działań, nastawionych na wdrażanie młodzieży do kanonów kultury. Prawdę mówiąc, praktyka szkolna może nawet stać w sprzeczności z innymi obecnymi w kulturze metodami wdrażania młodzieży do wymogów życia w społeczności" (2010, s. 3).

Wielokulturowość podmiotów szkolnych powinna z założenia prowadzić ku „tożsamości międzykulturowej” i do kulturowego uwrażliwiania (Nikitorowicz, 2007). Zdaniem Nikitorowicza „postrzeganie odmienności (...) odbywa się przez pryzmat naszych potrzeb, oczekiwań, stereotypów i uprzedzeń, wszelkich doświadczeń oraz racjonalnych i irracjonalnych przekonań" (2007, s. 105). Można w związku z tym przyjąć, że poglądy na wielokulturową prze- 
strzeń szkoły i jej doświadczanie w naturalnych codziennych interakcjach są wynikiem nie tylko określonych habitusów jako wzorców i konsekwencji socjalizacji pierwotnej, lecz również konsekwencją procesów nauczania-uczenia się, jakim podlegają uczniowie w szkole. Czy szkoła zatem może zmieniać wrażliwość kulturową i jak to się odbywa w praktyce szkolnej?

Przyjęcie w podjętej refleksji koncepcji edukacji Brunera kieruje nas w stronę uznania wielości kultur za czynnik rozwoju społeczeństwa demokratycznego i obywatelskiego, na co wskazuje w „modelu różnych kierunków interakcji w warunkach wielości kultur” Nikitorowicz (2007, s. 107). Autor „wielość kultur” definiuje przez przyjęcie „odmienności idei, wartości, programów, nastawień i oczekiwań, potrzeb, koncepcji rozwoju, mitów, stereotypów, uprzedzeń, dialogu i komunikacji" (tamże). W efekcie może ona prowadzić zdaniem autora ku:

- asymilacji i wchłanianiu,

- akceptacji i wzajemnemu uznaniu,

- akceptacji i hermetyczności kultury,

- „trzeciej” kulturze.

Wielość kultur i wzajemne interakcje wobec nich są warunkiem określonych zachowań społecznych, nacechowanych albo ksenofobią, albo wzajemnym zainteresowaniem i szacunkiem. Owa wzajemność prowadzi do rozwoju, współpracy, stymuluje i pozwala na konstruowanie nowych tożsamości, nie zamykając ich w okowach radykalizmów i braku akceptacji wobec Innych. Nikitorowicz określa te tożsamości w kategoriach tożsamości rozproszonej, wielopłaszczyznowej, „rozszczepionej” (2007, s. 105) Odpowiednia recepcja odmienności i różnic kulturowych w każdej przestrzeni społecznej jest warunkiem wzajemnego rozwoju. Bruner, postrzegając kulturę jako kontekst edukacji, uważa, że „życie umysłowe człowieka rozwija się bowiem poprzez dzielenie się z nim z innymi, komunikację, wymianę, a to wszystko jest możliwe tylko dzięki używaniu kodów kulturowych, odwoływaniu się do tradycji, podzielaniu znaczeń z innymi uczestnikami życia społecznego" (Brzezińska, 2010, XVI). Szkoła według Brunera jest niezwykłym miejscem, „aby pojąć, jak używać umysłu, w jaki sposób odnosić się do autorytetów, jak traktować innych" (2010, s. 116). Powołując się na przykład wykluczania przez przedszkolaków z zabawy „obcego” w zamian za uznanie przez grupę za „swojego”, wskazuje on na analogie typowe dla praktyk szkolnych. Według Brunera „wykluczenie dziecka z grupy bawiących się rówieśników jest prototypem tego rodzaju praktyk, które później przyjmujemy za prawdę oczywistą w naszych zmaganiach ze światem. Stają się (...) treścią naszej codzienności, która na- 
daje kształt naszym uprzedzeniom i predyspozycjom" (Bruner, 2010, s. 117). Można zatem założyć, że postawy wobec „obcych” pojawiające się w praktyce edukacyjnej mogą stanowić źródło zachowań społecznych w późniejszych etapach rozwoju jednostek i grup.

W teoretycznej analizie koncepcji Brunera dotyczącej znaczenia kultury w edukacji oraz refleksji nad edukacją dialogową i kulturowym kontekstem szkoły nie można pominąć istoty programu Head Start. J. Bruner był jednym z jego architektów, a w rezultacie program stanowił źródło dociekań i tworzenia przez niego psychologii kulturowej. Program ten uruchomiony został w 1964 roku przez rząd Stanów Zjednoczonych, a jego celem była stymulacja rozwojowa dzieci w wieku przedszkolnym ze środowisk kulturowo zaniedbanych. Obejmował on dzieci amerykańskie oraz dzieci imigrantów i Indian. Do chwili obecnej Program Head Start zajmuje się stymulowaniem rozwoju dzieci i przygotowaniem ich do osiągnięcia gotowości szkolnej, oferując usługi edukacyjne (indywidualizacja nauczania, planowanie, kompetencje społeczne i emocjonalne, umiejętność czytania, uczenie się języka), żywieniowe, zdrowotne (badania jamy ustnej, zdrowie psychiczne) i społeczne (stabilność mieszkaniowa, bezpieczeństwo finansowe, relacje rodzinne) (Raport, Office of Head Start). Obecnie poza dziećmi w wieku przedszkolnym program obejmuje niemowlęta, kobiety w ciąży w ramach komponentu Early Head Start. W dalszym ciągu programem objęci są Indianie - American Indian and Alaska Native (AIAN) i migranci - Migrant and Seasonal Head Start (MSHS) (Raport Head Start, 2018).

J. Bruner, uznając znaczenie kultury dla edukacji, wykorzystał swoje wieloletnie doświadczenia w ramach Programu Head Start w konstytuowaniu się stanowisk teoretycznych w ramach psychologii poznawczej. Sam program uznał za źródło rodzenia się nowej świadomości wśród osób podlegających kulturowej deprywacji i uznał, że „dostatecznie wczesna ingerencja w scenę rozwoju dziecka może prowadzić do zmiany jego późniejszego życia" (2010, s. 110). Z drugiej strony, mimo zmian mentalnych u dzieci objętych Programem, jego zaprzepaszczanie na etapie edukacji szkolnej może w niewystarczający sposób kształtować potrzeby społeczne i aspiracje edukacyjne. Bruner, mimo niedoskonałości Programu, wskazuje jednak na kwestie związane ze sposobem nauczania, dającego dziecku poczucie uczestnictwa w aktywującej się społeczności. W takim przypadku zdaniem Brunera nieistotne są aspekty środowiskowe. Niezależnie od tego, czy dziecko pochodzi z klasy średniej, czy doświadczyło ubóstwa i wykluczenia społecznego, aktywowanie go w procesie edukacyjnym stanowi radykalną zmianę w kształtowaniu jego 
potrzeb. Stworzenie mu warunków edukacyjnych włączających we wspólnotę klasową minimalizuje poczucie wyobcowania i bezradności. Badania niemieckie potwierdzają znaczenie kontaktów rówieśniczych w warunkach socjalizacji kulturowej, co pozytywnie wpływa na poczucie przynależności, budowania samooceny ze strony „mniejszości” (Vietze, Yuang i Schachner, 2019).

J. Bruner stawia zatem na konieczność budowania w szkole tzw. kultury „aktywizującej” (2010, ss. 114-115). Jako przykład podaje projekt szkolny, w którym zaangażowani uczniowie, niezależnie od ich kulturowej proweniencji i statusu ekonomicznego ich rodzin, zostali włączeni do opracowania planu. Dotyczył on wycieku ropy naftowej u wybrzeży Alaski z tankowca Exxon Valdez (2010, s. 114). Poczucie wspólnoty i "nauczanie przez dzielenie się" możliwościami i sposobami przeciwdziałania skutkom ekologicznym opracowywanego planu, niezależnie od statusu socjometrycznego dziecka w klasie, ma znaczenie dla późniejszego rozwoju społecznego i wspomaga uczenie się. Zwłaszcza dla dziecka ubogiego dostarczanie różnorodnych przykładów kultury stanowi zdaniem Brunera „specyficzny sposób przeciwdziałania niepożądanym efektom wyobcowania, bezradności i bezcelowości” (tamże). Przykład stanowią koreańscy imigranci w Ameryce, uzyskujący lepsze wyniki w badaniach testem inteligencji, niż koreańscy imigranci w Japonii, gdzie - jak podaje Bruner - "są pogardzani, izolowani i traktowani jako "gorsi«, podczas gdy w Ameryce postrzega się ich jako »bardzo bystrych «" (2010, s. 115). Dialogowość i włączanie w poczucie wspólnotowości jest warunkiem rozwoju nie tylko jednostek - zwłaszcza tych żyjących w poczuciu deprywacji kulturowej - ale także szkoły i jej kultury organizacyjnej. Deprywację kulturową określa Bruner jako „brak wyidealizowanych, właściwych amerykańskiej klasie średniej, skoncentrowanych na dziecku praktyk wychowawczych" (2010, s. 118). Ocenia jednocześnie, że pojęcie to zawężano, nie włączając w nie kwestii tożsamości kulturowych, zróżnicowania etnicznego i zmarginalizowanych warstw społecznych. Pojęcie deprywacji kulturowej było zatem w koncepcjach edukacji J. Brunera pojęciem bliskim semantycznie kategorii nierówności społecznych i procesom stratyfikacji społecznej, obejmującej osoby z niższych społecznie grup oraz imigrantów i uchodźców (Gmerek, 2011). Tymczasem w rozumieniu J. Brunera „świadomość działania, dobra szkoła i zdrowa klasa szkolna mogą dostarczyć dziecku ubogiemu, nawet obcemu dziecku imigrantów, pewnych działających wyobrażeń o tym, jak może funkcjonować społeczeństwo" (Bruner, 2010, s. 117). Wspólnota w uczeniu się, egalitaryzm, równoważność opinii i ocen wszystkich uczestników edukacji 
szkolnej stanowią istotny element edukacji dialogowej, na której opierać powinna się praktyka edukacyjna zwłaszcza w warunkach jej wielokulturowości. Bruner konstruuje wizję przedszkoli i szkół w spolaryzowanym ekonomicznie i kulturowo społeczeństwie amerykańskim jako instytucji konstruktywnie dostosowujących się do przemian społeczno-kulturowych. Jak twierdzi: „to pociąga za sobą budowanie kultur szkolnych, funkcjonujących w oparciu o wzajemność wspólnoty uczących się, razem angażujących się w rozwiązywanie problemów i przyczyniających się tym samym do rozwoju procesu nauczania wzajemnego. Grupy takie stanowią nie tylko przestrzeń nauczania, ale również ośrodek tożsamości i wspólnej pracy. Pozwólmy tym szkołom być miejscem dla praktyki (...) kulturowej wzajemności (...)” (Bruner, 2010, s. 120).

\section{Edukacja dialogowa - praktyka edukacyjna i realia wielokulturowych szkół}

Odnosząc założenia J. Brunera do szkoły jako wspólnoty uczącej się, gdzie uczenie staje się „partycypacyjne, proaktywne, wspólne, kooperatywne i nastawione raczej na tworzenie znaczeń niż na ich przyjmowanie w gotowej postaci" (2010, s. 122), warto byłoby skonfrontować je z sytuacją edukacyjną w polskich szkołach. W każdej z nich mamy do czynienia z nierównościami społecznymi; zwłaszcza w tych, których kultury szkolne są kreowane w warunkach wielokulturowości jej podmiotów. Jej konsekwencją są różnice językowe (różne kapitały społeczno-kulturowe), tym bardziej że są one zauważalne w obrębie „większości”, nie mówiąc o uczniach reprezentujących różne kultury narodowe i etniczne. Posiadany przez dziecko kapitał lingwistyczny jest warunkiem rozpoznawania „złożonych struktur logicznych bądź estetycznych i posługiwania się nimi" (Bourdieu i Passeron, 1990, s. 131). W warunkach różnic kulturowych i dyskursu „większości” staje się barierą utrudniającą proces edukacji w klasie szkolnej. Język jako narzędzie socjalizacji prowadzi do selekcji szkolnych, pozostawiając jednostki lub grupy ze środowisk mniej uprzywilejowanych społecznie (w tym także imigrantów, przedstawicieli mniejszości etnicznych) poza dopuszczalnym i uprawomocnionym kulturowo zakresem interakcji społecznych „większości”. Zdaniem T. Gmerka „język grupy dominującej stanowi element narzucania określonych dyskursów (uznanych za uprawomocnione i jedynie właściwe) grupom podporządkowanym" (2014, s. 56). Jej przedstawiciele w strukturze klasy szkolnej posługują się językiem polskim jako drugim językiem, którego przyswojenie jest zależne od wielu czynników i determinuje cały proces 
socjalizacji dziecka w grupie kulturowo dla niego innej. Osiągnięcia szkolne dziecka kulturowo „odmiennego” wyznaczane są stopniem opanowania języka określanego w lingwistyce jako L2. W. Klein uznaje za istotne w nauczaniu drugiego języka: motywację, zdolności językowe, tempo, dostęp do języka, strukturę jego przyswajania (2007, s. 93). Badacze wskazują na różne modele uczenia się drugiego języka, ze wskazaniem na konieczność tzw. edukacji biligwalnej lub inaczej - równoległej. Polega ona na jednoczesnym uczeniu się języka rodzimego i języka większości. Na kwestię tę zwraca uwagę H. Kyuchukow, badający procesy edukacyjne dzieci romskich w Bułgarii. Uznaje on biegłość w znajomości języka etnicznego za warunek zrównoważonego nauczania drugiego języka i osiągnięcia funkcjonalnej wiedzy bilingwalnej (2014, ss. 211-225). Opisywane w psycholingwistyce zjawisko submersji jest rodzajem dwujęzyczności zubażającej, polegającej na dominacji języka „większości", co zaburza wzajemne interakcje obu stron (Ellis, 2007). Kontekst kulturowy staje się płaszczyzną dominacji „większości” z jednoczesną izolacją społeczną „mniejszości”. Edukacja w warunkach uprawomocnienia „większości” prowadzi do delegalizacji kultury „mniejszości” i staje się naturalnym mechanizmem społecznym, który szkoła „wciela” w zachowania społeczne swoich uczniów i uczestniczy tym samym w inkubacji postaw opartych na stereotypach, uprzedzeniach, a nawet ksenofobii. Zostają one przenoszone na szersze kręgi społeczne i są określane przez B. Bernsteina skutkiem kulturowej reprodukcji znaczeń (Bielecka-Prus, 2010).

Różnice językowe w klasie szkolnej wymagają indywidualizacji pracy z uczniem, uwzględnienia jego kultury rodzimej z jednoczesnym włączaniem w pracę dydaktyczną, opartą o wspólne uczenie się. Jest to możliwe, przy założeniu konieczności rozwijania własnych kompetencji kulturowych i świadomości kontekstu kulturowego u nauczyciela (Szczurek-Boruta, 2002).

Konstruowanie wiedzy w szkole, co poddaje gruntownym studiom Dorota Klus-Stańska, jest złożonym procesem. Obejmuje wiedzę nauczyciela i wiedzę ucznia, komunikowanie się na lekcji, planowanie dydaktyczne (2002, ss. 65-67). Wiedza ucznia jest konsekwencją wiedzy nauczyciela i - zdaniem D. Klus-Stańskiej - opiera się na dialogu rozumiejącym, zdolności do „reinterpretacji”, prawie do „nieposłuszeństwa w myśleniu”, świadomości istnienia wielu „możliwych światów” i „myśleniu twórczym” (2002, s. 66). Ów dialog odbywający się w przestrzeni wielokulturowej klasy dotyczy wszystkich jej uczestników, co może kształtować ich wiedzę w oparciu o różne kody kulturowe. Wynikające z nich różnice powinny stać się czynnikiem rozwoju indywidualnego i transmisji kulturowej sprzyjającej wzajemnemu komunikowa- 
niu się na lekcji. D. Klus-Stańska, nawiązując do J.S. Brunera i L. Wygotskiego w odniesieniu do roli mowy i rozwoju języka, podtrzymuje tym samym tezę o społecznym charakterze procesu uczenia się (2002, ss. 55-57). L. Wygotski (1989) uważa bowiem, że źródłem konstruowania wiedzy jest nie umysł, lecz interakcje społeczne. Te zaś są podstawą uczenia się i rozwoju.

Rola nauczyciela jako organizatora pracy w klasie polega na stworzeniu płaszczyzny porozumiewania się i wsparcia w nim uczniów o niższym potencjale lingwistycznym, pod warunkiem że ma on świadomość pedagogiczną różnic kulturowych swoich uczniów i potrafi ją wykorzystać (Ogrodzka-Mazur, 2008). Jeśli jawi się ona jako atut, a nie dysonans poznawczy - choć taki z pewnością pojawia się w toku pracy w klasie zróżnicowanej kulturowo - nauczyciel sytuacje szkolne i procesy poznawcze może kształtować przez dialog, rozumiany jako interakcje społeczne rówieśników. Każda interpretacja i obraz świata (niezależnie od prezentowanych kodów kulturowych) prowadzi do rekonstrukcji znaczeń i nadania rzeczywistości nowej jakości. Rozumienie dynamiki procesów społecznych w klasie przez nauczyciela to dostrzeganie „osobistych znaczeń biograficznych światów poznawczych i językowych” (Klus-Stańska, 2010, s. 264). Autorka zaznacza wielość interpretacji pojęcia dialogu w edukacji, od bardzo powierzchownego ujmowania go w kategoriach „oczywistych” do dialogu opartego na konstruowaniu wiedzy szkolnej. Może się to odbywać nie w kontekście wiedzy monologowej i prostym przekazie, lecz wynikać „z doświadczania chaosu poznawczego, zdolności budowania teorii, szukania nowych konsekwencji, zadawania przez ucznia pytań" (2002, s. 90). W warunkach wielokulturowej klasy ów chaos poznawczy wynika z różnorodnych kodów kulturowych, czasem zupełnie sprzecznych i wykluczających się. Dialog oparty o schemat czy model prezentowany wyżej jest edukacją pozwalającą na wymianę myśli, w tym znaczeń i wartości, poszerzenie perspektywy społecznej i kulturowej, w jakiej funkcjonują podmioty szkolne. Jak określa wspomniana autorka, „edukacja dialogowa zakłada wielość prawomocnych systemów wiedzy, otwartość na nowe znaczenia, aktywność interpretacyjną ucznia w procesie ich konstruowania i społeczną negocjowalność obrazu rzeczywistości" (2002, s. 94). W ujęciu D. Klus-Stańskiej ten rodzaj edukacji w przeciwieństwie do monologu, opartego na niekwestionowanej roli nauczyciela i instrumentalnym przekazie wiedzy, prowadzi do nawiązania relacji między uczestnikami, zwiększenia zainteresowania, motywacji i sensu wspólnych działań, buduje poczucie sprawstwa w tworzeniu wspólnych rozwiązań i budowaniu znaczeń i opisów rzeczywistości (2002, s. 402). 
Tymczasem w edukacji, w tym w środowiskach wielokulturowych szkół, spotykamy się ze zjawiskiem „przemocy symbolicznej”. Pod rzekomymi hasłami edukacji międzykulturowej czy tolerancji, przy jednostronnym kształceniu językowym i obowiązującym dyskursie, dzieci reprezentujące inne kultury narodowo-etniczne poddane są procesom internalizacji kodów kulturowych „większości” (Szkudlarek, 2010). Interferencja kultur w przypadku zróżnicowanej kulturowo klasy nie ma zatem miejsca. Edukacja w tym przypadku stanowi swoistą przemoc wyrażaną ujednoliceniem przyswajanych kodów, niezależnie od różnic. J. Bruner (2010, s. 140) uważa, że „szkoła sama jest kulturą, a nie tylko »przygotowaniem « do uczestnictwa w kulturze (...)", co skłania nas do konstatacji o niskiej kulturze uczenia się czy nauczania w szkołach stosujących „przemoc symboliczną” w sposób mniej lub bardziej zamierzony. Przeświadczenie, że „większość” jest lepsza, a „mniejszość” inna, a zatem gorsza, staje się w procesach edukacyjnych w warunkach wielokulturowych szkół poważną zaporą dla rozwoju międzykulturowego myślenia i działania. Przejawia się ona w braku właściwych interakcji kulturowych i - niewspierana edukacją dialogową, prowadzoną w sposób kompetentny i zaplanowany przez nauczycieli - prowadzi ku niezdolności myślenia, konceptualizacji świata i jego interpretacji. Czy rzeczywiście odkrywanie, wzajemne uczenie się, wspólny przekaz i zadawanie pytań są domeną polskiej szkoły? Czy fakt obecności w niej uczniów kulturowo różnych jest tożsamy z edukacją międzykulturową i ideą opartą o tolerancję i zrozumienie dla odmienności w polskiej edukacji? Bruner uważa, że „uczenie się w całej właściwej mu złożoności polega na tworzeniu i negocjowaniu znaczeń w szeroko rozumianej kulturze, której kapłanem jest nauczyciel” (2010, s. 123), z przynależnym do niego zadaniem wprowadzania zmian i doskonalenia procesów nauczania i uczenia się. Dialog w edukacji w warunkach wielokulturowej klasy wymaga podniesienia kompetencji lingwistycznych nauczycieli. W wielu badaniach socjolingwistycznych wskazuje się na konieczność budowania interakcji w klasie i zapewnienia pomocy metalingwistycznej, co pomaga uczniom z L2 w rozwijaniu wiedzy i unikaniu ich niepowodzeń szkolnych (Shabani, 2016). Nauczyciele mogą osiągać znaczące efekty, stosując metajęzyk, lub też przez znajomość języka ucznia kulturowo innego. Dialog jest także zwiększeniem zaangażowania uczniów i służy podnoszeniu jakości interakcji w klasie. Pozwala on nauczycielom docenić głos uczniów i promować refleksyjną naukę (Lyle, 2008). Tyle tylko, że nie jest powszechną w polskich szkołach praktyką edukacyjną w wielokulturowych klasach. Przykładem jest chociażby mniejszość romska. W wielu szkołach dzieci romskie pozostają poza zasięgiem 
wieloletnich oddziaływań edukacyjnych szkoły, co wynika ze słabej znajomości języka polskiego, a jednocześnie myślenia. Posługiwanie się w Romani tylko formą mówioną (bez języka pisanego) utrudnia opanowanie języka polskiego, wykluczając tym samym dzieci romskie z kręgu interakcji z polskimi rówieśnikami. Powszechne uczenie się $\mathrm{w}$ formie nauczania indywidualnego w domu ogranicza ich rozwój poznawczy, emocjonalny i społeczny, a „większość" w klasie pozbawia szansy na poznanie odrębności kulturowej Romów i dialog z nimi (Dobrowolska, 2019). Szkolne niepowodzenia dzieci romskich prowadzą je często ku szkołom specjalnym, co Romowie uznają za działania dyskryminacyjne (Kołaczek i Talewicz-Kwiatkowska, 2011). Polskie szkoły nie wypracowały jak dotąd strategii pracy z dziećmi romskimi; winę ponoszą dwie strony - romska i polska - a dialog między nimi najwyraźniej nie ma miejsca. Egzemplifikacją wspomnianych wyżej praktyk i szkolnej rzeczywistości są wyniki badań obejmujące różne przestrzenie edukacyjne w polskich szkołach z obecnością dzieci romskich, czeczeńskich i wietnamskich (Dobrowolska, 2019). Każdą z nich cechuje bardzo indywidualny charakter, co pozwoliło w efekcie na wyróżnienie trzech modeli przestrzeni szkolnych:

- modelu monopolizacji przestrzeni z cechami stratyfikacji społecznej wobec mniejszości (obecność dzieci czeczeńskich),

- modelu wzajemnej akceptacji różnic z pełną akulturacją mniejszości (obecność dzieci wietnamskich),

- modelu deklarowanej tolerancji wobec wielokulturowości z izolacją społeczną mniejszości (obecność dzieci romskich) (Dobrowolska, 2019, s. 572).

Wyodrębnienie trzech modeli przestrzeni szkolnej jest konsekwencją różnic w obszarze obowiązujących dyskursów, związków z kulturą własną i internalizacją kodów kulturowych „większości”, identyfikacji ze szkołą, akceptacją versus odrzuceniem zachowań kulturowo odmiennych, wyznaczaniem ram społecznych, interakcji (przyjaźnie i konflikty), różnic w kapitałach społeczno-kulturowych, stopnia akulturacji „mniejszości”. W kontekście podjętych w artykule rozważań teoretycznych skłania to do pytania: jaką rolę odgrywa nauczanie oparte na dialogu i wspólnym poznaniu w konstytuowaniu się określonych kultur szkolnych i modeli wielokulturowych przestrzeni społecznych szkół? Czy dialogowość i wzajemna aktywizacja stanowią dydaktyczny paradygmat w edukacji szkolnej?

Wskazany model monopolizacji przestrzeni z cechami stratyfikacji spotecznej wobec mniejszości oraz model deklarowanej tolerancji wobec wielokulturowości z izolacją społeczna mniejszości potwierdzają istniejącą praktykę 
szkolną, w której nie uwzględnia się jej różnych kontekstów kulturowych. Wydaje się, że stratyfikacja czy też izolacja nie miałyby racji bytu w sytuacji wzajemnego uczenia się, dialogu, zdolności do „reinterpretacji” czy świadomości istnienia wielu „możliwych światów” (Klus-Stańska, 2002, s. 66). Odniesienie do objętej badaniami praktyki edukacyjnej nie pozwala jednak na generalizację tej opinii. Z pewnością wiele szkół prowadzi działania zmierzające do wypracowania międzykulturowego dialogu w zróżnicowanych narodowościowo i etnicznie klasach. Być może jego brakiem są złożone uwarunkowania legislacyjno-organizacyjne oraz niewystarczające kompetencje kulturowe nauczycieli.

\section{Podsumowanie}

Określenia J. Brunera dotyczące rozważań nad kulturą edukacji zamykają się w konkluzji: „chodzi nie tylko o przemianę szkoły jako kultury uczenia się, ale również zmianę roli nauczyciela w tej kulturze uczenia się i (...) również w szeroko rozumianym kontekście kulturowym" (2010, s. 124).

Wielokulturowe środowisko klasy jest z założenia strefą najbliższego rozwoju w szkole, będąc podstawową przestrzenią aktywności dzieci. Ta zaś według L. Wygotskiego (1989) jest podstawą dla uczenia się, rozwoju języka jako narzędzia myśli i interakcji społecznych. J. Bruner uznaje szkołę za miejsce aktywnego uczenia się, opartego o dobre metody strukturyzowania wiedzy i wzajemne angażowanie się w aktywny dialog, gdzie uczenie się jest procesem aktywnym i procesem społecznym, z punktu widzenia sytuacji, w jakiej przebiega (Brzezińska, 2010, XIV-XV). Coraz bardziej zróżnicowane kulturowo instytucje edukacyjne w Polsce (począwszy od przedszkola do kształcenia na poziomie akademickim) wymagają dyskusji nad strategią edukacji i dydaktycznymi rozwiązaniami. „Szkoły i przedszkola wyobrażam sobie zatem - mówi J. Bruner - jako placówki pełniące odnowioną funkcję w społeczeństwach doświadczających przemian. To pociąga za sobą budowanie kultur szkolnych, funkcjonujących w oparciu o wzajemność wspólnoty uczących się, razem angażujących się w rozwiązywanie problemów i przyczyniających się tym samym do rozwoju procesu nauczania wzajemnego. Grupy takie stanowią nie tylko przestrzeń nauczania, ale również ośrodek tożsamości i wspólnej pracy. Pozwólmy tym szkołom być miejscem dla praktyki (...) kulturowej wzajemności, co oznacza rozbudzanie w dzieciach świadomości tego, co robią, jak robią i dlaczego (Bruner, 2010, ss. 119-120). Tę wypowiedź J. Brunera uzupełnia następująca konstatacja: „równowaga między efektyw- 
nością jednostki a wydajnością grupy zostaje wypracowana wewnątrz kultury danej grupy: również równoważenie tożsamości etnicznych lub rasowych i pojęcie szerszej społeczności, której część stanowią" (2010, s. 120). Szkoła, wraz z wielokulturowym kontekstem uczestników szkolnej edukacji, winna tworzyć własną, wewnętrzną kulturę, opartą o dialog, gdzie doświadczanie, przekaz społeczny i refleksja (Filipiak, 2012, s. 64) prowadzą ku wzajemnemu poznaniu się i konstruowaniu wiedzy o świecie. Wiedza ta nie jest reprodukcją wiedzy nauczyciela, lecz pożądaną w dydaktyce konstrukcją nowych znaczeń i postrzegania świata w oparciu o różne poglądy, wizje i kody kulturowe. W spotkaniach ze światem kulturowo różnym współpraca i refleksja powinny stanowić podstawowy dyskurs, wyznaczany przez dialogowy model edukacji szkolnej. I jak podkreśla J. Nikitorowicz (2017, s. 83) - „kultura zawiera w sobie immanentnie dialog, a idea dialogu jest immanentnie zawarta w edukacji”, co staje się sentencją dla praktyki pedagogicznej.

\section{Bibliografia}

Bielecka-Prus, J. 2010. Transmisja kultury w rodzinie $i$ w szkole. Teoria Basila Bernsteina. Warszawa: Wydawnictwo Naukowe PWN.

Bourdieu, P. i Passeron, J.C. 1990. Reprodukcja. Elementy systemu nauczania. Warszawa: Wydawnictwo Naukowe PWN.

Bruner, J. 2010. Kultura edukacji. Kraków: TAiWPN „Universitas”.

Brzezińska, A. 2010. Wstęp. W: Bruner, J.S.: Kultura edukacji. Kraków: TAiWPN „Universitas”, ss. V-XX.

Dobrowolska, B. 2019. Społeczna przestrzeń szkoty i wielokulturowość w dziecięcym obrazie świata. Studium socjopedagogiczne. Siedlce: UPH.

Ellis, R. 2007. Czynniki społeczne w przyswajaniu drugiego języka. W: Kurcz,

I. red. Psychologiczne aspekty dwujęzyczności. Gdańsk: GWP, ss. 173-226.

Filipiak, E. 2012. Rozwijanie zdolności uczenia się. Z Wygotskim i Brunerem w tle. Gdańsk: GWP.

Gmerek, T. 2011. Edukacja i nierówności społeczne. Kraków: Oficyna Wydawnicza „Impuls”.

Klein, W. 2007. Przyswajanie drugiego języka. Proces przyswajania języka. W: Kurcz, I. red. Psychologiczne aspekty dwujęzyczności. Gdańsk: GWP, ss. 89-136.

Klus-Stańska, D. 2002. Konstruowanie wiedzy w szkole. Olsztyn: UWM. Klus-Stańska, D. 2010. Dydaktyka wobec chaosu pojęć i zdarzeń. Warszawa: Wydawnictwo Akademickie „Żak”. 
Kołaczek, M. i Talewicz-Kwiatkowska, J. red. 2011. Funkcjonowanie poznawcze i językowe dzieci romskich uczęszczających do szkót specjalnych. Oświęcim: Stowarzyszenie Romów w Polsce.

Kyuchukov, H. 2014. Acguisition of Romani in bilingual context. Psychology of Language and Communication. 18, (3), p. 211-225.

Lyle, S. 2008. Dialogic teaching:discussing theoretical contexts and reviewing evidence from classroom practice. Language and Education. 22 (3). https://www.tandfonline.com/doi/full/10.1080/09500780802152499?sr$\mathrm{c}=$ recsys $(12.01 .2020)$.

Nikitorowicz, J. 2007. Edukacja międzykulturowa. Kreowanie tożsamości dziecka. Gdańsk: GWP.

Nikitorowicz, J. 2017. Etnopedagogika w kontekście wielokulturowości i ustawicznie kształtującej się tożsamości. Kraków: Oficyna Wydawnicza „Impuls".

Ogrodzka-Mazur, E. 2008. „Nowy profesjonalizm” nauczyciela w kontekście przygotowania do edukacji międzykulturowej. W: Lewowicki, T., Ogrodzka-Mazur, E. i Szczurek-Boruta, A. red. Praca nauczyciela w warunkach wielokulturowości - studia $i$ doświadczenia z pogranicza polsko-czeskiego. Cieszyn - Toruń: Wydział Etnologii i Nauk o Edukacji Uniwersytetu Śląskiego, Wydawnictwo Adam Marszałek, ss. 25-72.

Raport Head Start Program facts: Fiskal Year 2018. U.S. Departament of Health \&Human Services. https://eclkc.ohs.acf.hhs.gov/about-us/article/ head-start-program-facts-fiscal-year-2018 (9.01.2020).

Raport, Office of Head Start. https://www.acf.hhs.gov/ohs/reports (9.01.2020).

Shabani, K. 2016. Implications of Vygotsky's sociocultural theory for second language (L2) assessment. Cogent Education. 1 (3). https://www.tandfonline.com/doi/full/10.1080/2331186X.2016.1242459?utm_source=TrendMD\&utm_medium $=$ cpc\&utm_campaign $=$ Cogent_Education_TrendMD_0 (12.01.2020).

Szczurek-Boruta, A. 2002. Swój i obcy w interpersonalnej przestrzeni społecznej (uwarunkowania kształtowania stereotypów i uprzedzeń etnicznych w warunkach wielokulturowości. W: Lewowicki, T., Nikitorowicz, J., Pilch, T. i Tomiuk, S. red. Edukacja wobec ładu globalnego. Warszawa: Wydawnictwo Akademickie „Żak”, ss. 165-176.

Szkudlarek, T. 2010. Pedagogika krytyczna. W: Kwieciński, Z. i Śliwerski, B. red. Pedagogika. Podręcznik akademicki. Warszawa: PWN, ss. 363-377.

Vietze, J., Yuang, L.P. and Schachner, M.K. 2019. Peer cultural socialisation: 
a resource for minority students' cultural identity, live satisfaction and

school values. Intercultural Education. 30 (5), ss. 579-598.

Wygotski, L.S. 1989. Myślenie i mowa. Warszawa: PWN.

\title{
Dialogue education versus the cultural context of school in the background of Jerome S. Bruner's concept. Classroom meetings with the culturally diverse world
}

\begin{abstract}
The article is theoretical and is a reflection on the cultural context of school, including Jerome S. Bruner's concept. The existing research on the Polish school and the multiculturalism of its students indicates its various models and the need for dialogue education. This leads to determining how learning in a multicultural school co-occurs with its discourse. The theoretical analysis of the problems raised in the article concerns the role of contemporary school and its meetings with a culturally different world, a place of intercultural dialogue and dialogue learning. Based on the concept of J.S. Bruner, the article is an attempt to determine the importance of various habituses of school education participants and their impact on the development and culture of school itself. The theoretical issue is also the reproduction of the "majority" culture in the school education process and the students constructing knowledge about the world, giving it meaning in conditions of cultural diversity. The idea of dialogue education with J.S. Bruner's concept and its theoretical contexts were compared with some examples of educational practice and the school reality.
\end{abstract}

Keywords: dialogue education, culture, Jerome S. Bruner's concept, multiculturalism, intercultural education 